\title{
Toward Inclusive STEM Classrooms: What Personal Role Do Faculty Play?
}

Tess L. Killpack ${ }^{* *}$ and Laverne C. Melón*

'Department of Biological Sciences, Wellesley College, Wellesley, MA 02481; ‘Department of Neuroscience, Tufts University School of Medicine, Boston, MA 02111

\begin{abstract}
Private and public policies are increasingly aimed at supporting efforts to broaden participation of a diverse body of students in higher education. Unfortunately, this increase in student diversity does not always occur alongside changes in institutional culture. Unexamined biases in institutional culture can prevent diverse students from thriving and persisting in science, technology, engineering, and mathematics (STEM) fields. Given the daily personal interactions that faculty have with students, we suggest that individual educators have the opportunity, and responsibility, to improve the retention and persistence of diverse students. However, in our experience, faculty professional development programs often limit discussions of diversity to "comfortable" topics (such as learning styles) and miss opportunities to explore deeper issues related to faculty privilege, implicit bias, and cues for stereotype threat that we all bring to the classroom. In this essay, we present a set of social science concepts that we can extend to our STEM courses to inform our efforts at inclusive excellence. We have recommended strategies for meaningful reflection and professional development with respect to diversity and inclusion, and aim to empower faculty to be change agents in their classrooms as a means to broadening participation in STEM fields.
\end{abstract}

\section{INTRODUCTION}

As access to postsecondary education rises, the demographic profiles of degree-granting institutions are slowly coming to reflect those of the country as a whole. Over the past 35 years, the percentage of enrolled college students who are Latino increased from 4 to $15 \%$ and the percentage of enrolled college students who are black rose from 10 to $15 \%$. Further, in the past decade, the number of enrolled students over age 25 rose by 35\% (Snyder and Dillow, 2013). Many institutions of higher education have actively recruited diverse students, with an acknowledgment that increased interactions with diverse peers enhance students' educational experiences and bring measurable improvements in learning outcomes for all (Kurlaender and Orfield, 1999; Gurin et al., 2002; Milem et al., 2005). In science, technology, engineering, and mathematics (STEM) fields, recognition of a demographic gap has resulted in policy changes to broaden participation by students from historically underrepresented groups. Multiple public and private initiatives have undoubtedly helped to increase these students' participation in STEM. Indeed, according to National Science Foundation statistics, the past decade has seen a rise in the number of underrepresented minority students majoring in many STEM subfields (National Science Foundation, 2013).

Unfortunately, the commitment to diversity at the level of enrollment practices and student recruitment does not always occur concomitantly with changes in the diversity of the faculty and administrative leadership (Flowers and Moore, 2008; Kena et al., 2015) or with changes in the institutional culture (Williams, 2007; Williams et al., 2005). This issue was powerfully highlighted by recent successful organizing by students of color across multiple universities calling for campus action against overt or subtle racist practices (Dean, 2015; Roberts, 2015). It is becoming clear that, as institutions of
Pat Marsteller, Monitoring Editor

Submitted January 15, 2016; Revised May 30, 2016; Accepted June 3, 2016

CBE Life Sci Educ September 1, 2016 15:es3 DOI:10.1187/cbe.16-01-0020

*Address correspondence to: Tess L. Killpack (tkillpac@ awellesley.edu).

(c) 2016 T. L. Killpack and L. C. Melón. CBE-Life Sciences Education () 2016 The American Society for Cell Biology. This article is distributed by The American Society for Cell Biology under license from the author(s). It is available to the public under an Attribution-Noncommercial-Share Alike 3.0 Unported Creative Commons License (http://creativecommons.org/licenses/ by-nc-sa/3.0).

"ASCB®" and "The American Society for Cell Biology $\AA^{\prime \prime}$ are registered trademarks of The American Society for Cell Biology. 
higher education increase compositional diversity, they must also ensure that they cultivate intellectual and social environments where all students have the opportunity to achieve academic success.

To better support our students and to ensure that campus diversity efforts are substantial and sustainable, the American Association of Colleges and Universities has proposed an "Inclusive Excellence" model for institutional change. This model mandates that measurements of the success of diversity and inclusion efforts become meaningfully integrated into the measurements of the academic quality of the institution (Williams, 2007; Williams et al., 2005). To achieve inclusive excellence, institutions must strategically invest in and coordinate inclusivity efforts and create a campus culture that welcomes and values students' cultural diversity (Bauman et al., 2005; Milem et al., 2005; Williams et al., 2005).

Given our daily roles in fostering student academic development, we faculty have an important opportunity, and responsibility, to effect change in our STEM classrooms. A recent report showed that $20 \%$ of Latino students and $40 \%$ of black students who intended to major in the natural sciences in their first year of college do not earn natural sciences degrees; for white and Asian students, the percent loss is 1.5 and $7 \%$, respectively (National Science Board, 2016). Positive classroom climates and teaching practices have been shown to improve persistence and academic and emotional development among diverse college students (Cabrera et al., 1999). Inclusive and equitable teaching practices have a greater influence on STEM performance and confidence in students' abilities to pursue STEM careers than do the students' own background characteristics (Cabrera et al., 2001; Colbeck et al., 2001). Therefore, we faculty can contribute to inclusive excellence in STEM by transforming our own pedagogical decisions and interactions to cultivate a positive climate and equitable educational outcomes for our students (Bauman et al., 2005; Milem et al., 2005).

As early-career academics, we have been disappointed by the lack of resources available to inform and support faculty's diversity efforts in STEM classrooms. This is troubling, as we are expected to detail in persuasive diversity commitment statements how we specifically intend to create inclusive classroom environments, and faculty on search committees are expected to adequately evaluate these statements. With respect to training in STEM pedagogy, we have encountered an infectious and welcomed energy to make evidence-based improvements to our teaching traditions. Unfortunately, we have found our training regarding diversity and inclusion is often limited to discussions on learning styles. Though learning style may be one valid component of diversity, how do other aspects of our multifaceted identities - such as race, class, gender identity-influence interactions in the classroom? Further, when we fail to consider these important elements of student and faculty identity, are we impairing learning outcomes for our students?

We are coming to realize that social identities and issues have separable and synergistic effects on persistence of students in STEM (Carlone and Johnson, 2007). However, for many STEM faculty, there may be a lack of awareness of how our personal actions could be detrimental to the very students we are working so hard to keep. Thankfully, our colleagues in the social sciences have produced a wealth of scholarship that may inform our STEM pedagogy. From this scholarship we believe that a basic approach to begin personal reflection and infusion of inclusive excellence into our STEM classrooms should be 1) minding the privilege gap between our students and ourselves when developing our courses, 2) acknowledging and confronting implicit biases, and 3) mitigating stereotype threat in our classrooms. To empower STEM faculty to embrace this threefold approach, each of the three sections of this essay provides a synthesis of relevant concepts and findings from social science literature, extensions of those concepts to our STEM classrooms, and recommendations for applying the concepts to our pedagogical practices.

\section{PRIVILEGE AND BELONGING IN THE COLLEGE STEM CLASSROOM}

Our students have a wide range of experiences and ultimate scientific goals. To cultivate inclusive excellence in our STEM classrooms, we cannot assume or expect that students newly arriving to our fields will automatically assimilate into existing classroom cultures (Williams et al., 2005). If we model our classrooms after those in which we found success as students, we may be inadvertently benefiting the students who have backgrounds, interests, or resources similar to ours. To ensure that we create equitable environments where all students feel welcomed, valued, and supported, we must consider how our own privileges and sense of belonging in our fields may differ from those of our students (Milem et al., 2005).

As faculty, we all have experienced unique obstacles along the road to pursuing our advanced degrees and career goals. Yet many of us have also benefited from privileges that have helped us arrive at our current positions at the front of a college STEM classroom. Privileges are elements of our identities that provide us with unrequested advantages and make it more likely for us to find success and belonging in a particular social system (Johnson, 2006). Though we cannot change the circumstances that we were born into or the historical events that shaped our current social systems, it is important to acknowledge that our own sets of privileges can influence our experiences and paths in ways that differ from someone who does not share the same privileges.

Privileges can derive from demographic factors (e.g., race, gender identity, class) and beneficial social connections, and they can influence the success, talent development, and persistence of students in STEM (Noble et al., 1999; Kerr et al., 2012). For example, if your family members have earned college degrees or work in STEM fields, it is likely that you (perhaps unknowingly) gained information about how to navigate the academic and scientific world that has advantaged you in your career (Sonnert, 2009). Or, if you did not have to work during your semesters or summers at college, you may have been privileged to take part in extracurricular activities or research internships that helped you to grow your résumé and make yourself marketable postgraduation (Furr and Elling, 2000; Leppel, 2002; Kulm and Cramer, 2006). Taking stock of all of our unacknowledged advantages and bringing them into our consciousness can be difficult, but it is important for our development as educators aiming to create equitable classroom environments.

Demographic and social identities, such as race, ethnicity, and socioeconomic and immigration statuses, are associated with recognizable privileges that can underlie differential 
advantages in the United States. In her influential essay about white privilege, Dr. Peggy McIntosh (1988) notes, "I can easily find academic courses and institutions which give attention only to people of my race" (p. 7) and "I can go home from most meetings of organizations I belong to feeling somewhat tied in, rather than isolated, out-of-place, outnumbered, unheard, held at a distance or feared" (p. 6). These are only two items on a list of 46 daily advantages that McIntosh conceived were not afforded to her black coworkers and friends. One could imagine generating similar lists regarding privileges associated with age, gender, nationality, socioeconomic status, heterosexuality, able-bodiedness, and more. Scholars who facilitate teacher-training programs note that we educators must thoroughly examine our own privileges and the social systems that support them to fully be able to successfully and equitably teach diverse students (St. Denis and Schick, 2003; Seidl and Hancock, 2011; Yu, 2012).

We all have a multifaceted set of identities that are important to us or that society places upon us, and each identity confers varying degrees of privilege or disadvantage. When working toward inclusive excellence, we must enhance awareness of the intersectional nature of our and our students' identities. Intersectionality was first used as a scholarly framework to highlight the unmet needs of black women, whose membership in two marginalized groups often meant that their unique position went ignored in legal and policy changes aimed to improve either gender or racial inequities (Crenshaw, 1991). Intersectionality has since broadened its reach to highlight the overlapping and often synergistic marginalized identities of individuals. As a black woman building an academic career in the sciences (L.C.M.), I have experienced explicit racial and gender discrimination. However, I realized that I took many of my other privileged identities for granted when facilitating my courses. For example, I recently created an introductory neuroscience seminar on sex differences in the brain. As the course progressed, thoughtful questions from my transgender (i.e., discordance between social gender identity and identity assigned at birth) students helped me realize that I unintentionally omitted neuroscience studies that included trans subjects. Such studies would have indeed been relevant to the course and of interest to the entire class. I could have reflected on my cisgender (i.e., concordance between my social gender identity and my identity assigned at birth) privilege while designing this course to create a seminar that would have increased inclusive excellence for a greater portion of my students.

In addition to privilege, we should consider that sense of belonging to the scientific community has an important impact on persistence in STEM, even among highly qualified and driven graduate students and $\mathrm{PhDs}$ in the biological sciences (Gibbs et al., 2014, 2015). Undergraduate students are often first introduced to STEM research in our classrooms, and feeling like worthy participants in the scholarship of STEM can have a big influence on their tenacity in these courses (Hurtado et al., 2010). There are noticeable elements in the identity of many of the scientists we highlight in our STEM courses that may indicate to students that they are not the "norm" in our fields. Margaret Mead and Rhoda Métraux's classic study of thousands of student essays showed that high schoolers possess a consistent perception of scientists as old men in lab coats who stay indoors (Mead and Metraux, 1957). David Chambers'
Draw-A-Scientist test demonstrated that, more than a decade later, students illustrated the very same characteristics identified in those essays (Chambers, 1983; Finson et al., 1995). A host of follow-up studies support the persistence of this singular image of the scientist and suggest that even students at the college level continue to endorse a pervasive image of scientists as white and male (Finson, 2002). Although there are recognized limitations to the interpretation of these drawings (Schinske et al., 2015), the persistence of some of the stereotyped characteristics of scientists depicted across these studies is concerning. For students who do not identify with some or all of those qualities, we may see erosion in their sense of belonging (Carlone and Johnson, 2007), which could lead to them leaving STEM fields altogether.

\section{Recommendations}

1. As a first step to increase inclusive excellence in our STEM classrooms, we must turn a critical eye to how our pedagogy instincts may be influenced by our own experiences, privileges, and multifaceted identities (Banks and Tucker, 1998). Then we can gather data from our students to ensure that we are not inadvertently disadvantaging some students over others when designing our courses. We (T.L.K. and L.C.M.) assign precourse surveys at the start of the semester to assist us with making equitable course decisions. For example, if a majority of our students live off campus, have jobs, or are the primary caretakers for children or family members, we may decide against scheduling office hours at a time when our students may be commuting, working, or transporting their children to and from school or day care. Or, if students rely on campus computer labs for Internet access or printing facilities, we may use that information to inform the timing of deadlines and the mode (paper vs. electronic) for submitting course work. These actions help to remove structural barriers so that all students have the opportunity to perform to their highest potential.

2. We should highlight the important contributions of scientists who are from groups that are underrepresented in STEM. We serve our students by introducing the important discoveries of these scientists and refuting the false trope of all significant scientists as white, male, or unidimensional. We can examine what scholarship we instinctually choose to share in our courses and make efforts to infuse findings and assigned readings from a diverse set of scientists. We (T.L.K. and L.C.M.) also share photos of these scientists and their lab groups (often posted on institutional websites) to provide our students with images of diverse scientists and the collaborative nature of research. Recent work shows that highlighting the complex identities of scientists as real-life individuals works to evolve students' stereotypical impression of scientific scholars (Painter et al., 2006). These efforts to diversify the imagery of scientists must be repeatedly and meaningfully embedded into the fabric of the course to effectively update students' stereotypical views (Bodzin and Gehringer, 2001) and to communicate to our multidimensional students that they belong in STEM. Many of us are in unique positions as scientist-educators to highlight the intersectionality of our own identities (as female, LGBQTIA, Latino/a, working-class, etc.), and this may play a small role in helping students update their scientist trope. This suggests 
that even taking the time on the first days of our courses to introduce students to us, as individuals, may be worthwhile.

3. We should acknowledge that our classrooms may be filled with students who have different motivations and aspirations than we had when we were in their seats. When we are facilitating courses that serve as an introduction to the general fields of biology, neuroscience, engineering, and so on, we can incorporate students' varied interests into the course design to broaden interest and participation in STEM. New faculty may find that participating in career panels or meeting with specialty student clubs before beginning the first semester at an institution can go a long way to help us learn about who our students are and what their goals are for their paths through STEM. We can also incorporate opportunities for student choice in their assignments so that they can make connections between the content and their own personal STEM interests. For example, many students feel motivated by scientific findings that have specific implications for their communities. For these "altruistic scientists" (Carlone and Johnson, 2007), a focus on health and application of basic science concepts to address community challenges may increase their persistence in STEM. Increasing our recognition of our students as multidimensional, legitimate members of our STEM communities can increase our students' science identities and help maintain their interests in STEM careers (Carlone and Johnson, 2007).

\section{PERVASIVE IMPLICIT BIASES AND THEIR INFLUENCE ON OUR THOUGHTS AND ACTIONS}

As educators interested in promoting inclusive excellence in STEM fields, we believe in treating and evaluating all of our students equitably. However, a rich body of social psychology research shows that we are all vulnerable to biased judgments that operate without our awareness and that can impact our interactions and decision making. From a young age, stereotypes related to race, gender, sexuality, and religion (to name a few) are learned and reinforced through our daily exposure to embedded societal messages and social interactions (Collins, 2008). These sociocultural influences lead us to internalize a set of automatic associations, known as implicit biases, that can become unconsciously activated in response to a stimulus associated with a pervasive stereotype (Devine, 1989; Banaji et al., 1993). What can be surprising and upsetting is that ingrained stereotype-based biases can habitually influence our thoughts and behaviors, even when those biases conflict with personal beliefs and values that we control with conscious thought processes (Carnes et al., 2005, 2012; Devine et al., 2012). Therefore, inhibiting stereotypic responses requires more than an activation of conscious personal beliefs; it requires an inhibition of automatic associations caused by our implicit biases (Devine, 1989).

But how can we identify our implicit biases when they are unconscious in nature? The development of Implicit Association Tests (IATs; Greenwald et al., 1998, 2003) has allowed for measurement of implicit biases associated with race, religion, sexuality, disability (and more) and has revealed their pervasiveness among people. During the IAT, test takers are instructed to use the computer keyboard to make rapid associations between a concept (e.g., black or white) and an evaluation or stereotype (e.g., good or bad). The latency in decision making by the test taker is recorded by the computer. The main idea behind the IAT is that implicit biases are revealed if the test taker makes faster associations when presented with stereotype-congruent pairings (photos of white people with terms that denote "good" things, photos of black people with terms that denote "bad" things) than when presented with the related stereotype-incongruent pairings.

The IAT can reveal the amazing power that societal messages have in influencing our unconscious thoughts. Interestingly, according to Project Implicit (projectimplicit.org), which hosts and collects data from online IATs, even people who identify as members of a stereotyped group can show unconscious biases toward that group. The implication for us as scientists and STEM educators is that, even if we are well-intentioned people who believe in equity and our own personal objectivity, we are susceptible to unconscious biases. According to data collected by Project Implicit from a gender bias in science IAT, more than $50 \%$ of Web respondents showed a moderate to strong automatic association of males with science and females with liberal arts. My personal (T.L.K.) results on this IAT revealed that I make a slight unconscious association of men with science. This was surprising, given that I am a woman in science myself, I served as president of the Graduate Women in Science during graduate school, and I teach biology at an all-women's college. Taking this and other IATs gave me a unique opportunity to actively bring unconscious biases, some of which I never expected to possess, to my awareness.

Research shows that our unconscious biases can affect our judgments and behaviors. Indeed, a meta-analysis of 122 studies suggested that the results of IATs are better at predicting interracial and intergroup discriminatory behavior than self-report measures (Greenwald et al., 2009). While analyses by experts in the field have found slight variations in the degree to which IATs exactly predict intergroup discriminatory behavior (Oswald et al., 2013; Greenwald et al., 2015), the main message is clear: unconscious biases can have a substantial societal impact given that they can influence the behavior of many people simultaneously and/or that behaviors influenced by bias could be repeatedly performed by individuals.

Research shows that unconscious biases of teachers could influence our classroom interactions and impede our efforts at inclusive excellence for our STEM students. First, unconscious biases can influence the expectations that we hold for diverse students, which can reduce their performance. A study of Dutch teachers showed that teachers' levels of implicit bias (measured by IAT) were related to their differential academic expectations for ethnic majority versus ethnic minority students and to the size of the ethnic achievement gap in their classrooms (Van den Bergh et al., 2010). Additionally, teachers often create "warmer" social and emotional climates when they have high expectations for students' abilities (Rosenthal, 2002, 2003). This "warmth" is often communicated through subtle, spontaneous, and often unintended modes of communication (Rosenthal, 2002, 2003), which are influenced by implicit racial biases (Dovidio et al., 2002).

Second, our unconscious biases can also lead us to inaccurate judgments about our students' abilities. For example, a research group provided elementary school teachers with a student name and a short vignette about a student and asked each teacher to rate his or her perception of the student's 
achievement motivation in school. While the vignette describing the student was exactly the same, if a white-sounding name was attached to it the student was given significantly higher scores than if a black-sounding name was provided (Anderson-Clark et al., 2008). In another study, high school math teachers were asked to offer their personal assessments of whether their students were enrolled in an appropriate level of math course. Across all levels, white male students were significantly more likely to be judged as being in a course that was "too easy" for them, despite having the same grade point average and math test scores as white females in the same course (Riegle-Crumb and Humphries, 2012). From these two examples, we can see how implicit race and gender biases can influence what should be objective evaluations of our students.

Finally, the effects of implicit biases can go beyond the classroom to impact our students' successes along their paths to STEM careers. In a recent randomized double-blind study, university science faculty were asked to provide feedback on an undergraduate's application for a laboratory manager position (Moss-Racusin et al., 2012). The materials received by each faculty reviewer were identical, except that the applicant's first name was listed as either "John" or "Jennifer." Faculty who evaluated "John's" application provided higher ratings of competence and hirability than those who evaluated "Jennifer's." Reviewers of "John's" application also recommended a significantly $(12 \%)$ higher salary, and indicated an increased willingness to provide career mentoring for the student. Interestingly, the implicit bias that favored "John's" application over "Jennifer's" was evident in both male and female faculty reviewers and occurred in faculty across scientific fields (biology, chemistry, physics), age, and tenure status (Moss-Racusin et al., 2012).

The teachers and scientist reviewers in the cited studies likely did not intentionally disadvantage minority and female students and applicants or hold conscious beliefs about the innate abilities of certain races and genders. However, we can see that unconscious biases of educators can negatively impact student success in STEM through our nonverbal communication and through altered expectations and judgments of students. The effects of instructor biases are compounded by the findings that students bring their own negative implicit associations about the culture of STEM fields that influence their interest and sense of belonging (Kessels et al., 2006; Stout et al., 2011; Ramsey et al., 2013; Young et al., 2013). Given the pervasiveness and elusiveness of implicit biases about who is capable of succeeding in STEM, we faculty can examine our own biases and develop strategies to break the habit of biased thoughts and behaviors to promote inclusive excellence in our classrooms.

\section{Recommendations}

1. We can read more about how the IAT works and take free IATs online to explore our own implicit biases (https:// implicit.harvard.edu/implicit/takeatest.html). After taking several IATs, we will all likely discover that we have implicit biases toward some demographic groups. Believing in our abilities to make objective decisions or attempting to suppress stereotypic thoughts are counterproductive strategies (Monteith et al., 1998; Uhlmann and Cohen, 2007; Carnes et al., 2015). We can instead begin to use personal cognitive practices, such as actively identifying and negating stereotypical thoughts (Kawakami et al., 2000), affirming counter-stereotypes (Gawronski et al., 2008), or priming our minds to think differently and creatively in the face of stereotypes (Sassenberg and Moskowitz, 2005), to reduce our negative unconscious evaluations of people belonging to stereotyped groups. Additionally, engaging in meaningful interpersonal and cooperative interactions with diverse colleagues and students can significantly reduce prejudiced thoughts and actions (Berryman-Fink, 2006).

2. Becoming aware of our biases can be empowering if we have concrete strategies to address them (Devine et al., 2012). We can request and participate in quality diversity-focused courses and workshops to learn about and practice strategies to break our biased habits (Kernahan and Davis, 2007; Adams et al., 2008; Pettijohn and Walzer, 2008; Carnes et al., 2012; Devine et al., 2012; Jackson et al., 2014). Indeed, diversity education has been shown to reduce race-related biases among participants (Rudman et al., 2001). In one training program, participants took and received feedback on the black-white IAT and then learned how to implement bias-reduction strategies (Devine et al., 2012). Following this training intervention, participants showed reduced implicit biases on subsequent black-white IATs and increased self-reported awareness and concerns about biases and discrimination (Devine et al., 2012). A recent study showed the positive impact of a workshop that taught deliberate strategies to reduce gender-biased habits (Carnes et al., 2015). Faculty from medicine and STEM departments who participated in the workshop demonstrated increased personal awareness of biases and also reported increased motivation and belief in their abilities to promote equity. Of interest to our efforts toward inclusive excellence, participants reported more positive perceptions of their departmental climate after attending the workshop with their colleagues. Additionally, when at least $25 \%$ of a departments' faculty attended the workshop, participants reported significant increases in personal efforts to promote gender equity 3 months following the workshop (Carnes et al., 2015). Therefore, meaningful faculty diversity training has the potential to lead to substantial improvements in classroom climate and inclusive excellence in STEM.

3. Multiple studies have shown that unconscious biases, revealed in IATs, can lead to discriminatory thoughts and actions (Dovidio et al., 2002; Van den Bergh et al., 2010; Oswald et al., 2013; Greenwald et al., 2015). It is imperative that we rely on data, rather than potentially biased instincts, to influence our academic decision making (Banaji et al., 2003). Stereotypes and unconscious biases can lead to shifting evaluation criteria or position requirements during faculty searches or hiring processes and can result in inequities (Uhlmann and Cohen, 2005; Phelan et al., 2008; Isaac et al., 2009). We can implement systematic methods for grading and hiring, such as deidentifying documents before reviewing them and using predesigned rubrics and checklists to evaluate the quality of the assignment or application. These interventions can lead to more equitable interactions and decisions in our roles as faculty, which can contribute to inclusive excellence in our STEM departments. 


\section{FACULTY ACTIONS THAT CAN BE CUES FOR STEREOTYPE THREAT}

As described above, a narrow and deeply ingrained societal stereotype exists for scientists (Finson, 2002). Beyond that, research shows both teachers (Chang and Demyan, 2007) and students (Kao, 2000) in the United States have an awareness of both positive and negative stereotypes related to race and academic expectations. To increase inclusive excellence, we must examine how stereotypes can influence the climate and the student experiences in our STEM classrooms. A phenomenon called "stereotype threat" occurs when an individual is performing a difficult task on which members of their group are thought to stereotypically do poorly (Steele and Aronson, 1995). Stereotype threat can lead underrepresented students to feel additional mental and emotional pressure to succeed, which increases cognitive load, depletes working memory, and induces physiological stress (Spencer et al., 2016). Simply put, the extra pressure to succeed consumes mental and emotional resources that are then unavailable for problem solving.

Stereotype threat has been shown to negatively impact students' grades and test scores (Walton and Spencer, 2009) and their emotional well-being, sense of belonging, and motivation to persist in an academic field (Spencer et al., 2016). Interestingly, stereotype threat is more likely to occur when students self-identify with or feel strongly invested in the task (Osborne and Walker, 2006; Keller, 2007). It is therefore plausible that this phenomenon is responsible for some of the underperformance and underrepresentation of our most academically capable students.

Research shows that stereotype threat can be activated indirectly or subtly based on cues from faculty in the learning or assessment environment. For example, performance declines when students are primed to identify as members of a threatened social group before completing a difficult task. When black students were asked to identify their race before taking a Graduate Record Examination verbal exam, their performance was significantly lower than the performance observed in the white students and/or in the black students who were not asked to identify their race (Steele and Aronson, 1995). When Asian-American undergraduates were primed to think about their female identity before taking a math test, their math performance declined (Shih et al., 1999; Rydell et al., 2009). However, if students were primed to think about their Asian identity (Shih et al., 1999) or to think about their identity as a college student in addition to their female identity (Rydell et al., 2009), then the performance reduction disappeared. It becomes clear from these studies that faculty can trigger stereotype threat through seemingly innocuous identification cues, which are commonplace in our assessment environments.

Another subtle way that faculty may activate stereotype threat is by emphasizing that an academic task is a diagnostic measure of intelligence or ability. The extensive work of psychologist Dr. Carol Dweck and her colleagues has shown that the mind-sets people maintain regarding intelligence can impact their academic motivation. Individuals who use "fixed mind-sets" believe that intelligence is an entity that cannot be substantially changed, while those who use "growth mind-sets" believe that intelligence is incremental and can substantially increase throughout one's life (Dweck, 2008). Students with fixed mind-sets often focus on perfection, and avoid challenges, because they see obstacles as threats to their self-concept. Alternatively, students with growth mind-sets embrace challenges as opportunities to learn and grow, and they are more likely to persist in the face of setbacks (Dweck, 2008).

Setting a tone that communicates a fixed mind-set with respect to intelligence and abilities can trigger stereotype threat in students (Sawyer and Hollis-Sawyer, 2005). It can lead students to have greater cognitive activation of stereotypes and greater concerns about their own abilities and how their performances will be judged (Steele and Aronson, 1995). For example, female MBA students underperformed compared with male MBA students when a negotiation task was described as extremely diagnostic of negotiating ability (Kray et al., 2001). University students from low-socioeconomic backgrounds solved fewer problems on a verbal task if that task was described as an assessment of intellectual ability (Croizet and Claire, 1998). In both cases, if the same task was described to a control group as not being diagnostic of ability, equal performance was observed between male and female or low- and high-socioeconomic students. When considering our role in creating positive classroom climates, we must pay attention to these subtle cues that could be impacting our students' abilities to perform to their greatest potential.

\section{Recommendations}

1. We can work to alleviate stereotype threat by reducing situations that prime students to think about their membership in a negatively stereotyped group. For example, if we must gather demographic information about students' name, race, or gender, we can place that demographic page at the end of the survey or assessment (Miller and Tanner, 2015). Additionally, we can prime a relevant shared positive social identity, being a college student, to set a tone that all of the students in our courses were accepted to our institution, deserve to be there, and are capable of success (Rydell and Boucher, 2010; Rydell et al., 2009). We can also reduce stereotype threat through the way we frame our feedback on student performance. Cohen and colleagues (1999) showed that constructive feedback that communicates high standards, with assurances that the student is capable of meeting those high standards, is most effective in increasing motivation and decreasing student perceptions that they will be judged stereotypically.

2. We can also provide opportunities for student self-affirmation in our courses to alleviate stereotype threat (Critcher and Dunning, 2015). Providing students with an opportunity to reflect on things that they personally value or feel proud of can increase performance (Cohen et al., 2006; Martens et al., 2006). When we (L.C.M. and T.L.K.) teach, we type affirmation sentences as the first question of our exams and ask students to recopy them, in an effort to remove some "threat in the air" associated with assessments. We also ask students to periodically complete "minute papers" (Smith et al., 2009) during the semester to anonymously share something they enjoyed learning about or a skill they were proudly developing in the course as a means to engage students in positive reflection. A recent study also showed that academic achievement and 
TABLE 1. Guide for considering faculty roles in increasing inclusive excellence in STEM classrooms

\begin{tabular}{|c|c|c|c|}
\hline & $\begin{array}{l}\text { Minding the gaps of privilege } \\
\text { and belonging }\end{array}$ & $\begin{array}{l}\text { Acknowledging and reducing } \\
\text { implicit biases }\end{array}$ & $\begin{array}{l}\text { Mitigating stereotype threat } \\
\text { activation }\end{array}$ \\
\hline Take-home messages & $\begin{array}{l}\text { We must examine our privileges and } \\
\text { broaden our representations of } \\
\text { scientists to increase a sense of } \\
\text { belonging among our students. }\end{array}$ & $\begin{array}{l}\text { Internalized societal stereotypes result } \\
\text { in implicit biases that can lead to } \\
\text { harmful thoughts and actions if } \\
\text { left to the unconscious. }\end{array}$ & $\begin{array}{l}\text { Our classroom actions can activate } \\
\text { stereotype threat, which leads to } \\
\text { underperformance in academically } \\
\text { prepared students. }\end{array}$ \\
\hline \multirow[t]{2}{*}{ Prompts for reflection } & $\begin{array}{l}\text { What personal advantages have } \\
\text { assisted you on your career path? } \\
\text { How many of those are shared by } \\
\text { your students? }\end{array}$ & $\begin{array}{l}\text { What aspects of your course design } \\
\text { and approaches could shift to rely } \\
\text { on objective data rather than } \\
\text { instinct or habit? }\end{array}$ & $\begin{array}{l}\text { What does your teaching approach } \\
\text { communicate about who is capable } \\
\text { of succeeding in your courses? }\end{array}$ \\
\hline & $\begin{array}{l}\text { How can you expand representations } \\
\text { of scientists and applications of } \\
\text { STEM in your courses? }\end{array}$ & $\begin{array}{l}\text { How might your unchecked implicit } \\
\text { biases impact student success in } \\
\text { your courses? }\end{array}$ & $\begin{array}{l}\text { How can you work to remove the } \\
\text { "threats in the air" for students in } \\
\text { your courses? }\end{array}$ \\
\hline \multirow[t]{6}{*}{ Suggested reading } & \multicolumn{3}{|c|}{ Between the World and Me (Ta-Nehisi Coates) } \\
\hline & \multicolumn{3}{|c|}{ Blindspot: Hidden Biases of Good People (Mahzarin R. Banaji and Anthony Greenwald) } \\
\hline & \multicolumn{3}{|c|}{ It's the Little Things: Everyday Interactions That Anger, Annoy, and Divide Races (Lena Williams) } \\
\hline & \multicolumn{3}{|c|}{ Mindset: The New Psychology of Success (Carol S. Dweck) } \\
\hline & \multicolumn{3}{|c|}{ Waking Up White, and Finding Myself in the Story of Race (Debby Irving) } \\
\hline & \multicolumn{3}{|c|}{ Whistling Vivaldi: How Stereotypes Affect Us and What We Can Do (Claude M. Steele) } \\
\hline
\end{tabular}

persistence can be enhanced through a structured goal-setting activity that guides students to write about their ideal futures, prioritize and strategize their goals, plan for setbacks, and monitor their progress (Schippers et al., 2015). These self-affirmation interventions can replace students' "threatened" thoughts with positive ones to improve their experiences in our STEM classrooms.

3. Finally, we can encourage ourselves and our students to embrace a growth mind-set with respect to intelligence and ability (Dweck, 2008). This can enhance inclusive excellence by increasing student enjoyment of the process of learning in STEM courses. For example, when students were asked to complete a writing task describing intelligence as a malleable entity, grades as well as reported identification with and enjoyment of academics significantly increased among black students (Aronson et al., 2002). Additionally, when students read about the struggles that famous physicists encountered while making their inventions and discoveries, their interest in science increased and their problem solving and recall of key concepts improved (Hong and LinSiegler, 2012). Sharing our own "growth" experiences with students, such as rejected papers, failed grants, or indirect paths to our career goals, will set a tone for embracing the growth mind-set in our classrooms.

\section{CONCLUSIONS AND ACTION STEPS}

We as faculty are responsible for establishing positive classroom climates so that students who have newly arrived to STEM fields will stay and thrive (Cabrera et al., 1999; Colbeck et al., 2001; Bauman et al., 2005; Milem et al., 2005). By making a personal commitment to examine the impacts that our own privileges, implicit biases, and stereotype threat cues can have on our students' experiences, we can engage in the process of self-transformation that is an important step toward achieving inclusive excellence in our classrooms (Banks and Tucker, 1998; Milem et al., 2005). While initially this practice may make one feel overwhelmed or vulnerable, we believe readers can become empowered by their increased awareness of these phenomena and can use the concepts and recommendations provided as resources to effect change. We encourage faculty to use the provided guide (Table 1) as a reference while they begin this work. The take-home messages and prompts for reflection can help focus individual efforts to revamp course syllabi, materials, and approaches. Faculty may find it to be productive and rewarding to gather with colleagues to discuss these issues, or perhaps to start a book club with the suggested reading list. We believe these efforts by faculty will go a long way to broaden participation in our STEM fields, leading us all toward inclusive excellence.

\section{ACKNOWLEDGMENTS}

We thank guest editor Pat Marsteller and our anonymous reviewers for their thoughtful and constructive suggestions to improve this essay. We also thank Don Gillian-Daniel, Andrew Hooper, Eric Luth, Elena West, Amy Yu, and our colleagues in Training in Education and Critical Research Skills (TEACRS) and other Institutional Research and Academic Career Development Award (IRACDA) programs for thoughtful conversations and feedback. L.C.M. is supported by National Institutes of Health-National Institute of General Medical Sciences grant K12GM074869; an IRACDA training grant to Tufts University, TEACRS.

\section{REFERENCES}

Adams G, Edkins V, Lacka D, Pickett KM, Cheryan S (2008). Teaching about racism: pernicious implications of the standard portrayal. Basic Appl Soc Psych 30, 349-361.

Anderson-Clark TN, Green RJ, Henley TB (2008). The relationship between first names and teacher expectations for achievement motivation. J Lang Soc Psychol 27, 94-99.

Aronson J, Fried CB, Good C (2002). Reducing the effects of stereotype threat on African American college students by shaping theories of intelligence. J Exp Soc Psychol 38, 113-125

Banaji MR, Bazerman MH, Chugh D (2003). How (un) ethical are you? Harv Bus Rev 81, 56-64, 125. 
Banaji MR, Greenwald AG (2013). Blindspot: Hidden Biases of Good People, New York: Random House Publishing Group.

Banaji MR, Hardin C, Rothman AJ (1993). Implicit stereotyping in person judgment. J Pers Soc Psychol 65, 272.

Banks JA, Tucker M (1998). Multiculturalism's five dimensions. NEA Today 17, 17.

Bauman GL, Bustillos LT, Bensimon EM, Christopher M, li B, Bartee RD, Patterson FD (2005). Achieving Equitable Educational Outcomes with All Students: The Institution's Role and Responsibilities, Washington, DC Association of American Colleges and Universities.

Berryman-Fink C (2006). Reducing prejudice on campus: the role of intergroup contact in diversity education. College Student J 40, 511-516.

Bodzin A, Gehringer M (2001). Breaking science stereotypes. Sci Child 38, $36-41$.

Cabrera AF, Colbeck CL, Terenzini PT (2001). Developing performance indicators for assessing classroom teaching practices and student learning. Res High Educ 42, 327-352.

Cabrera AF, Nora A, Terenzini PT, Pascarella E, Hagedorn LS (1999). Campus racial climate and the adjustment of students to college: a comparison between white students and African-American students. J High Educ 70, 134

Carlone HB, Johnson A (2007). Understanding the science experiences of successful women of color: science identity as an analytic lens. J Res Sci Teach 44, 1187-1218.

Carnes M, Devine PG, Isaac C, Manwell LB, Ford CE, Byars-Winston A, Fine E, Sheridan J (2012). Promoting institutional change through bias literacy. J Divers High Educ 5, 63-77.

Carnes M, Devine PG, Manwell LB, Byars-Winston A, Fine E, Ford CE, Forscher P, Isaac C, Kaatz A, Magua W, et al. (2015). Effect of an intervention to break the gender bias habit for faculty at one institution: a cluster randomized, controlled trial. Acad Med J Assoc Am Med Coll 90, 221-230.

Carnes M, Handelsman J, Sheridan J (2005). Diversity in academic medicine: the stages of change model. J Womens Health 14, 471-475.

Chambers DW (1983). Stereotypic images of the scientist: the Draw-AScientist test. Sci Educ 67, 255-265.

Chang DF, Demyan AL (2007). Teachers' stereotypes of Asian, black, and white students. Sch Psychol Q 22, 91-114.

Coates T-N (2015). Between the World and Me, New York: Spiegel \& Grau.

Cohen GL, Garcia J, Apfel N, Master A (2006). Reducing the racial achievement gap: a social-psychological intervention. Science 313, 1307-1310.

Cohen GL, Steele CM, Ross LD (1999). The mentor's dilemma: providing critical feedback across the racial divide. Pers Soc Psychol Bull 25, 1302-1318

Colbeck CL, Cabrera AF, Terenzini PT (2001). Learning professional confidence: linking teaching practices, students' self-perceptions, and gender. Rev High Educ 24, 173-191.

Collins N (2008). Stereotype, Thousand Oaks, CA: Sage.

Crenshaw K (1991). Mapping the margins: intersectionality, identity politics, and violence against women of color. Stanford Law Rev 43, 1241-1299.

Critcher CR, Dunning D (2015). Self-affirmations provide a broader perspective on self-threat. Pers Soc Psychol Bull 41, 3-18.

Croizet J-C, Claire T (1998). Extending the concept of stereotype threat to social class: the intellectual underperformance of students from low socioeconomic backgrounds. Pers Soc Psychol Bull 24, 588-594.

Dean M (2015, December 29). Race on campus: the year of "making a statement on what America should be"; The Guardian interviews students at Yale, University of Missouri, Amherst College and Georgetown about how racial turmoil affected their year on campus. The Guardian.

Devine PG (1989). Stereotypes and prejudice: their automatic and controlled components. J Pers Soc Psychol 56, 5.

Devine PG, Forscher PS, Austin AJ, Cox WTL (2012). Long-term reduction in implicit race bias: a prejudice habit-breaking intervention. J Exp Soc Psychol 48, 1267-1278.

Dovidio JF, Kawakami K, Gaertner SL (2002). Implicit and explicit prejudice and interracial interaction. J Pers Soc Psychol 82, 62-68.

Dweck CS (2008). Mindset: The New Psychology of Success, New York: Ballantine.

Finson KD (2002). Drawing a scientist: what we do and do not know after fifty years of drawings. School Sci Math 102, 335-345.
Finson KD, Beaver JB, Cramond BL (1995). Development and field test of a checklist for the Draw-A-Scientist test. School Sci Math 95, 195-205.

Flowers LA, Moore JL III (2008). Unraveling the composition of academic leadership in higher education: exploring administrative diversity at 2-year and 4-year institutions. J Thought 43, 71-81.

Furr SR, Elling TW (2000). The influence of work on college student development. NASPA J 37, 454.

Gawronski B, Deutsch R, Mbirkou S, Seibt B, Strack F (2008). When "Just Say $\mathrm{No}^{\prime}$ is not enough: affirmation versus negation training and the reduction of automatic stereotype activation. J Exp Soc Psychol 44, 370-377.

Gibbs KD Jr, McGready J, Bennett JC, Griffin K (2014). Biomedical science Ph.D. career interest patterns by race/ethnicity and gender. PLoS One 9 , e114736.

Gibbs KD Jr, McGready J, Griffin K (2015). Career development among American biomedical postdocs. CBE Life Sci Educ 14, ar44.

Greenwald AG, Banaji MR, Nosek BA (2015). Statistically small effects of the Implicit Association Test can have societally large effects. J Pers Soc Psychol 108, 553-561.

Greenwald AG, McGhee DE, Schwartz JL (1998). Measuring individual differences in implicit cognition: the implicit association test. J Pers Soc Psychol 74, 1464.

Greenwald AG, Nosek BA, Banaji MR (2003). Understanding and using the Implicit Association Test: I. an improved scoring algorithm. J Pers Soc Psychol 85, 197-216.

Greenwald AG, Poehlman TA, Uhlmann EL, Banaji MR (2009). Understanding and using the Implicit Association Test: III. meta-analysis of predictive validity. J Pers Soc Psychol 97, 17-41.

Gurin P, Dey E, Hurtado S, Gurin G (2002). Diversity and higher education: theory and impact on educational outcomes. Harv Educ Rev 72, 330-367.

Hong H-Y, Lin-Siegler $X$ (2012). How learning about scientists' struggles influences students' interest and learning in physics. J Educ Psychol 104 469-484.

Hurtado S, Newman CB, Tran MC, Chang MJ (2010). Improving the rate of success for underrepresented racial minorities in STEM fields: insights from a national project. New Dir Inst Res 2010, 5-15.

Irving D (2014). Waking Up White, and Finding Myself in the Story of Race, Elephant Room Press.

Isaac C, Lee B, Carnes M (2009). Interventions that affect gender bias in hiring: a systematic review. Acad Med J Assoc Am Med Coll 84, 1440-1446.

Jackson SM, Hillard AL, Schneider TR (2014). Using implicit bias training to improve attitudes toward women in STEM. Soc Psychol Educ 17, 419-438

Johnson AG (2006). Privilege, Power, and Difference, New York: McGraw-Hill.

Kao G (2000). Group images and possible selves among adolescents: linking stereotypes to expectations by race and ethnicity. Sociol Forum 15, 407430.

Kawakami K, Dovidio JF, Moll J, Hermsen S, Russin A (2000). Just say no (to stereotyping): effects of training in the negation of stereotypic associations on stereotype activation. J Pers Soc Psychol 78, 871.

Keller J (2007). Stereotype threat in classroom settings: the interactive effect of domain identification, task difficulty and stereotype threat on female students' maths performance. Br J Educ Psychol 77, 323-338.

Kena G, Musu-Gillette L, Robinson J, Wang X, Rathbun A, Zhang J, Wilkinson-Flicker S, Barmer A, Dunlop Velez E (2015). The Condition of Education 2015, NCES 2015-144, Washington, DC: National Center for Education Statistics. https://nces.ed.gov/pubsearch/pubsinfo.asp?pubid $=2015144$ (accessed 5 January 2016)

Kernahan C, Davis T (2007). Changing perspective: how learning about racism influences student awareness and emotion. Teach Psychol 34, 4952.

Kerr BA, Multon KD, Syme ML, Fry NM, Owens R, Hammond M, Robinson-Kurpius $S$ (2012). Development of the distance from privilege measures: a tool for understanding the persistence of talented women in STEM. J Psychoeduc Assess 30, 88-102.

Kessels U, Rau M, Hannover B (2006). What goes well with physics? Measuring and altering the image of science. Br J Educ Psychol 76, 761-780.

Kray LJ, Thompson L, Galinsky A (2001). Battle of the sexes: gender stereotype confirmation and reactance in negotiations. J Pers Soc Psychol 80, 942-958. 
Kulm TL, Cramer S (2006). The relationship of student employment to student role, family relationships, social interactions and persistence. Coll Stud J 40, 927-938.

Kurlaender M, Orfield G (1999). In defense of diversity: new research and evidence from the University of Michigan. Equity Excell 32, 31-35.

Leppel K (2002). Similarities and differences in the college persistence of men and women. Rev High Educ 25, 433-450.

Martens A, Johns M, Greenberg J, Schimel J (2006). Combating stereotype threat: the effect of self-affirmation on women's intellectual performance. J Exp Soc Psychol 42, 236-243.

Mclntosh $P$ (1988). White privilege and male privilege: a personal account of coming to see correspondences through work in women's studies, Working Paper 189, Wellesley, MA: Wellesley Centers for Women.

Mead M, Metraux R (1957). Image of the scientist among high-school students: a pilot study. Science 126, 384-390.

Milem JF, Chang MJ, Antonio AL (2005). Making Diversity Work on Campus: A Research-Based Perspective, Washington, DC: Association American Colleges and Universities.

Miller S, Tanner KD (2015). A portal into biology education: an annotated list of commonly encountered terms. CBE Life Sci Educ 14, fe2.

Monteith MJ, Sherman JW, Devine PG (1998). Suppression as a stereotype control strategy. Pers Soc Psychol Rev 2, 63-82.

Moss-Racusin CA, Dovidio JF, Brescoll VL, Graham MJ, Handelsman J (2012). Science faculty's subtle gender biases favor male students. Proc Natl Acad Sci USA 109, 16474-16479.

National Science Board (2016). Science and Engineering Indicators 2016 NSB-2016-1, Arlington, VA.

National Science Foundation (2013). Women, Minorities, and Persons with Disabilities in Science and Engineering: 2013 Special Report, Arlington VA: National Science Foundation, National Center for Science and Engineering Statistics.

Noble KD, Subotnik RF, Arnold KD (1999). To thine own self be true: a new model of female talent development. Gift Child Q 43, 140-149.

Osborne JW, Walker C (2006). Stereotype threat, identification with academics, and withdrawal from school: why the most successful students of colour might be most likely to withdraw. Educ Psychol 26, 563-577.

Oswald FL, Mitchell G, Blanton H, Jaccard J, Tetlock PE (2013). Predicting ethnic and racial discrimination: a meta-analysis of IAT criterion studies. J Pers Soc Psychol 105, 171-192.

Painter J, Jones MG, Tretter TR, Kubasko D (2006). Pulling back the curtain uncovering and changing students' perceptions of scientists. School Sci Math 106, 181-190

Pettijohn TF, Walzer AS (2008). Reducing racism, sexism, and homophobia in college students by completing a psychology of prejudice course. Coll Stud J 42, 459-468.

Phelan JE, Moss-Racusin CA, Rudman LA (2008). Competent yet out in the cold: shifting criteria for hiring reflect backlash toward agentic women Psychol Women Q 32, 406-413.

Ramsey LR, Betz DE, Sekaquaptewa D (2013). The effects of an academic environment intervention on science identification among women in STEM. Soc Psychol Educ 16, 377-397.

Riegle-Crumb C, Humphries M (2012). Exploring bias in math teachers' perceptions of students' ability by gender and race/ethnicity. Gend Soc 26 , $290-322$.

Roberts N (2015). Black athletes at Mizzou on strike over university president's mishandling of campus racism. The Root. www.theroot.com/ articles/news/2015/11/mizzou_football_players_strike/ (accessed 5 January 2016)

Rosenthal R (2002). Covert communication in classrooms, clinics, courtrooms, and cubicles. Am Psychol 57, 839-849.

Rosenthal R (2003). Covert communication in laboratories, classrooms, and the truly real world. Curr Dir Psychol Sci 12, 151-154

Rudman LA, Ashmore RD, Gary ML (2001). "Unlearning" automatic biases: the malleability of implicit prejudice and stereotypes. J Pers Soc Psychol 81 $856-868$
Rydell RJ, Boucher KL (2010). Capitalizing on multiple social identities to prevent stereotype threat: the moderating role of self-esteem. Pers Soc Psychol Bull 36, 239-250

Rydell RJ, McConnell AR, Beilock SL (2009). Multiple social identities and stereotype threat: Imbalance, accessibility, and working memory. J Pers Soc Psychol 96, 949-966.

Sassenberg K, Moskowitz GB (2005). Don't stereotype, think different! Overcoming automatic stereotype activation by mindset priming. J Exp Soc Psychol 41, 506-514.

Sawyer J, Hollis-Sawyer LA (2005). Predicting stereotype threat, test anxiety and cognitive ability test performance: an examination of three models. Int J Test 5, 225-246.

Schinske J, Cardenas M, Kaliangara J (2015). Uncovering scientist stereotypes and their relationships with student race and student success in a diverse, community college setting. CBE Life Sci Educ 14, ar35.

Schippers MC, Scheepers AWA, Peterson JB (2015). A scalable goal-setting intervention closes both the gender and ethnic minority achievement gap. Palgrave Commun 1, 15014.

Seidl B, Hancock S (2011). Acquiring double images: white preservice teachers locating themselves in a raced world. Harv Educ Rev 81, 687-709.

Shih M, Pittinsky TL, Ambady N (1999). Stereotype susceptibility: identity salience and shifts in quantitative performance. Psychol Sci 10, 80-83.

Smith KA, Douglas TC, Cox MF (2009). Supportive teaching and learning strategies in STEM education. New Dir Teach Learn 117, 19-32.

Snyder TD, Dillow SA (2013). Digest of Education Statistics, 2012, NCES 2014-015, Arlington, VA: National Science Foundation, National Center for Science and Engineering Statistics.

Sonnert G (2009). Parents who influence their children to become scientists: effects of gender and parental education. Soc Stud Sci 39, 927-941.

Spencer SJ, Logel C, Davies PG (2016). Stereotype threat. Annu Rev Psychol $67,415-437$

St Denis V, Schick C (2003). What makes anti-racist pedagogy in teacher education difficult? Three popular ideological assumptions. Alta J Educ Res 40, 55-69.

Steele C (2011). Whistling Vivaldi: How Stereotypes Affect Us and What We Can Do, New York: W.W. Norton \& Company

Steele CM, Aronson J (1995). Stereotype threat and the intellectual test performance of African Americans. J Pers Soc Psychol 69, 797.

Stout JG, Dasgupta N, Hunsinger M, McManus MA (2011). STEMing the tide: using ingroup experts to inoculate women's self-concept in science, technology, engineering, and mathematics (STEM). J Pers Soc Psychol $100,255-270$

Uhlmann EL, Cohen GL (2005). Constructed criteria redefining merit to justify discrimination. Psychol Sci 16, 474-480.

Uhlmann EL, Cohen GL (2007). "I think it, therefore it's true": effects of self-perceived objectivity on hiring discrimination. Organ Behav Hum Decis Process 104, 207-223.

Van den Bergh L, Denessen E, Hornstra L, Voeten M, Holland RW (2010). The implicit prejudiced attitudes of teachers relations to teacher expectations and the ethnic achievement gap. Am Educ Res J 47, 497-527.

Walton GM, Spencer SJ (2009). Latent ability: grades and test scores systematically underestimate the intellectual ability of negatively stereotyped students. Psychol Sci 20, 1132-1139.

Williams DA (2007). Achieving inclusive excellence: strategies for creating real and sustainable change in quality and diversity. About Campus 12 8-14.

Williams DA, Berger JB, McClendon SA (2005). Toward a Model of Inclusive Excellence and Change in Postsecondary Institutions, Washington, DC Association of American Colleges and Universities.

Williams L (2002). It's the Little Things: Everyday Interactions That Anger, Annoy, and Divide the Races, Boston: Houghton Mifflin Harcourt.

Young DM, Rudman LA, Buettner HM, McLean MC (2013). The influence of female role models on women's implicit science cognitions. Psychol Women Q 37, 283-292.

Yu T (2012). What is it that I don't know? Learning with white teachers in anti-racist education. Multicult Educ 19, 47-52. 